(RESEARCH ARTICLE)

\title{
Effects of sublethal exposure of fungal xenoestrogen on oxidative stress and hepatic histology of tadpoles Rana saharica
}

Sana Benosmane ${ }^{1,}$, Amel Alayat ${ }^{2}$, Zine Eddine Boumedris ${ }^{3}$, Ouissem Moumeni ${ }^{4}$, Houria Berrebah 5 and Mohammed Reda Djebar ${ }^{5}$

${ }^{1}$ Nature and Life sciences Department, Faculty of Nature and Life Sciences and Sciences of the Earth and the Universe, 08 May 1945 University, Guelma, Algeria.

2 Department of Agronomy, Faculty of Sciences of Nature and Life, Chadli Bendjedid University, El Tarf, Algeria.

${ }^{3}$ Department of Biology, Faculty of Sciences of Nature and Life, Chadli Bendjedid University, El Tarf, Algeria.

${ }^{4}$ Department of Biology Sciences, Faculty of Natural and Life Sciences and Sciences of Earth and The Universe, Mohamed El-Bachir El-Ibrahimi University, Bordj Bou Arreridj, Algeria.

${ }^{5}$ Laboratory of Cellular Toxicology, Department of Biology, Faculty of sciences, Badji Mokhtar University, Annaba, Algeria.

Publication history: Received on 11 August 2020; revised on 06 September 2020; accepted on 12 September 2020

Article DOI: https://doi.org/10.30574/wjarr.2020.7.3.0300

\begin{abstract}
Xenoestrogens are artificial products that can be of industrial, agricultural or pharmaceutical origin. We have undertaken work to examine the possible effects of a stressor; a systemic fungicide considered to be an estrogen mimetic, Mancozebe, on tadpoles of an amphibian species; the green frog Rana saharica. After treatment for 5 weeks with increasing concentrations of Mancozeb $(0.25,0.50,0.75$ and $1 \mathrm{mg} / \mathrm{l})$. In order to evaluate the biochemical and metabolic aspect and to know the details of the oxidative stress, we performed some assays. A disturbance of the antioxidant detoxification systems (Glutathion-S-Transferase GST and Catalase CAT) which are involved in the defense mechanisms against stress caused by Mancozeb was highlighted. We also found an increase in Malondialdehyde (MDA) levels due to lipid peroxidation and neurotoxicity confirmed by inhibition of Acetylcholinesterase (AchE) activity. The induction of oxidative stress prompted us to explore, among other things, the histological side and tissue damage caused by Mancozeb in tadpoles. Our results revealed hepatocyte necrosis and cytoplasmic vacuolation.
\end{abstract}

Keywords: Oxidative stress; Xenoestrogen; Fungicide; Mancozeb; Tadpoles; Histology.

\section{Introduction}

Xenoestrogens are artificial products that can be of industrial, agricultural or pharmaceutical origin. Most of the work on the toxicological impact of xenoestrogens focuses on their pharmaceutical origin. Toxicological studies of xenohormones of agricultural origin are much neglected.

These compounds such as pesticides or plastics products are suspected of being endocrine disruptors. Of natural or synthetic origin, endocrine disruptors can alter the functioning of the hormonal system. These substances could therefore induce adverse effects on the health of an organism, its offspring, or a population, and therefore constitute a potential health hazard not yet assessed [1].

\footnotetext{
${ }^{*}$ Corresponding author: Sana Benosmane

Nature and Life sciences Department, Faculty of Nature and Life Sciences and Sciences of the Earth and the Universe, 08 May 1945 University, Guelma, Algeria.
} 
Several pesticides are on the list of endocrine disrupters, some of whose active molecules are now banned in Europe, but the majority is still used in third world countries [2].

Our problem consists in developing and analysing many aspects related to the toxicity of mimetic-oestrogens of agricultural origin: "Mancozeb" on pollution bioindicators, representative of the Amphibian group, the green frog Rana saharica, in the tadpole phase.

There is a need for indicators of environmental disturbance; organisms or a set of organisms that are used as sentinels by studying the physiological, biochemical and ecological changes that affect them. These living beings, which are highly sensitive to contaminants, have the advantage that they are more easily adapted than humans to the study of the effects of pollutants and make it possible to identify chronic or sudden pollution [3].

Our objective is to characterize the sensitivity of these organisms to Mancozeb from two aspects: the antioxidant response of these organisms and the endocrine disruption of this xenobiotic.

\section{Material and methods}

\subsection{Biological material}

The experiments were carried out on a freshwater species; the green frog: Rana saharica[4], which occurs in most of the humid regions of North Africa, also in northern Western Sahara, Tripoli and the oases of the Algerian Sahara [5].

\subsection{Chemical material}

We chose Mancozebe (Manganese Zinc Ethylene Zinc Bis Dithiocarbamate), a non-systemic fungicide belonging to the carbamate family. It is a dithiocarbamate, which includes Maneb and Metiram as active ingredients [6].

\subsection{Processing mode}

We have created an artificial milieu in the laboratory, with pH (between 7 and 9) and temperature (between 16 and $20^{\circ} \mathrm{C}$ ) of the medium to guarantee favourable conditions for the development of the tadpoles. The maintenance or monitoring of the parameters of comfort and breeding of the tadpoles is essential throughout the experiment because these amphibians are very sensitive to variations of $\mathrm{pH}$ and $\mathrm{T}^{\circ}$ [7].

Experiments are carried out on tadpoles in the early stages of larval development and end with the pre-metamorphosis stages [8], which impose a limited exposure period of 5 weeks.

We determined 04 concentrations of Mancozebe (C1, C2, C3, and C4) corresponding respectively to $0.25 ; 0.5 ; 0.75$ and $1 \mathrm{mg} / \mathrm{l}$ and a control sample (T) as well as an acetone control sample. Each batch is composed of 10 tadpoles.

These concentrations were selected from an LC50 from an acute toxicity test in fish and aquatic invertebrates $1 \mathrm{mg} / \mathrm{l}<$ LC50 $<10 \mathrm{mg} / \mathrm{l}$. (Product safety data sheet).

\subsection{Evaluation of oxidative stress}

For the assays to be carried out in the present study, the decapitated bodies were used for the determinations of the specific antioxidant activity of Catalase (CAT) and other biomarkers such as Glutathione S-transferase GST) and Malondialdehyde MDA. The heads of the tadpoles from the control series and treated with different concentrations of the estrogen mimetic (Mancozeb) were assayed for Acetylcholinesterase (AChE) activity. In parallel, and for the enzyme assays, the total protein concentration of the samples was previously determined according to the method of Bradford [9].

Assays were conducted on pre-metamorphosing tadpoles having approximately the same weight and linear characteristics.

\subsubsection{Measurement of Glutathione S-Transferase (GST) activity}

The measurement of GST activity is carried out according to the method of Habig et al.[10] based on the photometric measurement of the conjugation kinetics of the product formed with a substrate: 1-chloro-2,4-dinitrobenzene (CDNB) in the presence of a cofactor, Glutathione (GSH). 


\subsubsection{Catalase Activity Measurement (CAT)}

The Catalase activity (CAT) is determined according to the method of Regoli and Principato [11], which is based on the change in optical density resulting from the dismutation of hydrogen peroxide $\left(\mathrm{H}_{2} \mathrm{O}_{2}\right)$ at a wavelength of $240 \mathrm{~nm}$.

\subsubsection{Determination of Malondialdehyde (MDA)}

Lipid peroxidation is estimated by quantification of MDA using the method of Draper and Hadley [12]. This method is based on the colorimetric measurement of the reaction between Thiobarbituric acid (TBA) and Malondialdehyde (MDA), resulting in a reddish-brown product whose colour intensity is measured at a wavelength of $532 \mathrm{~nm}$.

\subsubsection{Measurement of Acetylcholinesterase (AchE) activity}

Our chosen method for the determination of Acetylcholinesterase (AChE) is that of Ellman et al. [13], in which the enzyme is provided with a substrate, Acetylthiocholine (ASCh), the hydrolysis of which releases Thiocholine (SCh) and acetic acid.

\subsection{Statistical study}

Statistical analysis of the data is performed by the Student's t-test. This test is performed using data analysis software: Minitab (Version 14.0) [14]. The results are represented by the mean \pm standard deviation.

\subsection{Histological study}

A histological study has been carried out to characterise tissue alterations and lesions according to the method of Martoja and Martoja [15].

\section{Results}

\subsection{Evolution of the Glutathione-S-Transferase activity}

According to Figure (1) we see that treatment of tadpoles with increasing concentrations of estrogen mimetic induces a significant increase $(\mathrm{p}=0.045<0.05)$ in GST enzyme activity compared to controls.

Indeed, the GST activity is on the order of $0.015 \mathrm{nM} / \mathrm{mg}$ protein in control individuals and increases by about $63 \%$ $(0.032 \mathrm{nM} / \mathrm{mg})$ in tadpoles treated with the lowest concentration (0.25 mg/l), while this increase is $84 \%(0.093 \mathrm{nM} /$ $\mathrm{mg}$ ) in tadpoles treated with the highest concentration (1 mg/l).

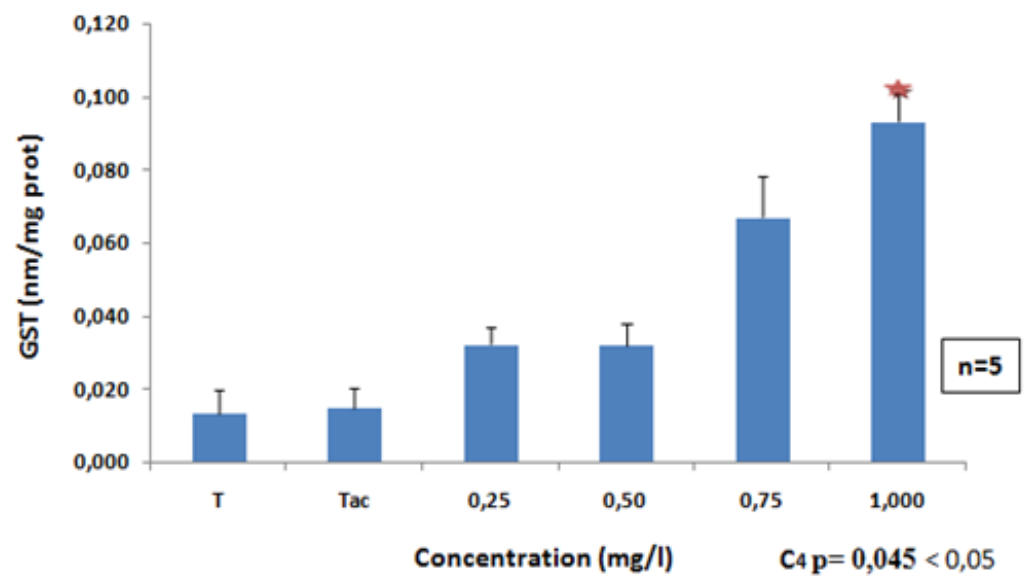

Figure 1 Effect of increasing Mancozeb concentrations on the evolution of GST activity in tadpoles (Rana Saharica).

\subsection{Evolution of the Catalase activity}

Figure (2) illustrates the evolution of CAT activity in tadpoles of Rana saharica treated with increasing concentrations of estrogen mimetic. This activity tends to increase in a dose-dependent and significant manner $(\mathrm{p}=0.038<0.05)$ in tadpoles treated with the lowest concentration $(0.25 \mathrm{mg} / \mathrm{l})$ and highly significant $(\mathrm{p}<0.001)$ in tadpoles treated with the highest concentrations compared to controls. 
Indeed, for the lowest concentration $(0.25 \mathrm{mg} / \mathrm{l}$ of Mancozeb) Catalase activity increases by $78 \%$ while in the highest concentration treated tadpoles Catalase activity increases by $80 \%$ to $85 \%$ compared to controls.

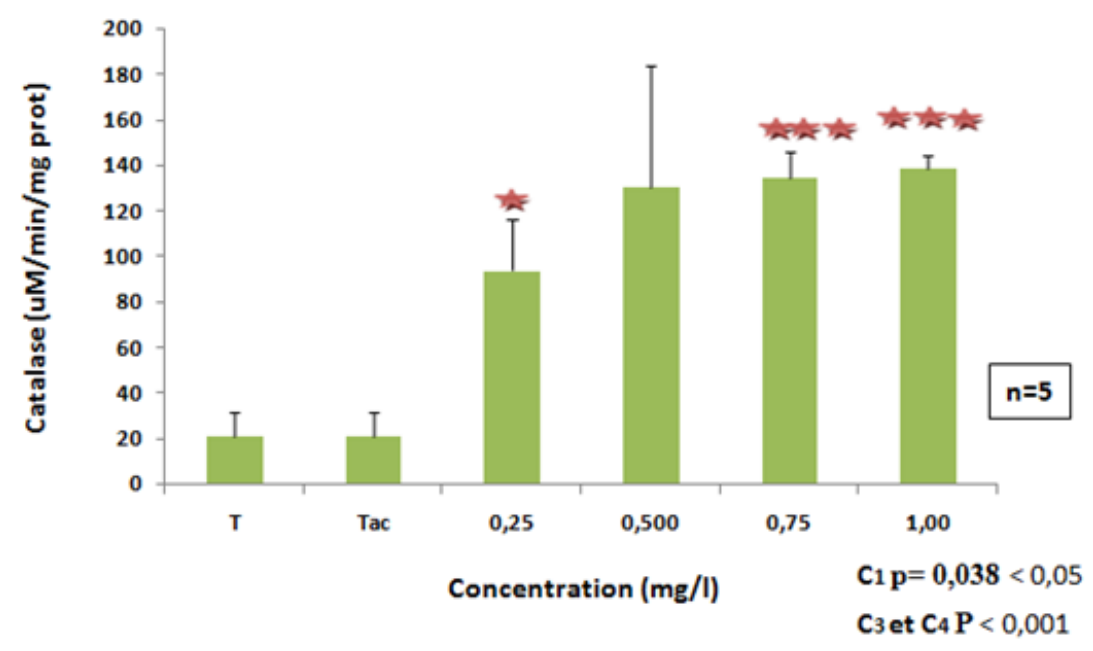

Figure 2 Effects of increasing Mancozeb concentrations on the evolution of CAT activity in tadpoles (Rana Saharica).

\subsection{Evolution of the level of Malondialdehyde}

Figure (3) shows the evolution of MDA content in tadpoles treated with increasing concentrations of fungicide. We see that the MDA level tends to increase in a dose-dependent manner. This increase is significant $(p=0.039<0.05)$ and is of the order of $53 \%$ for the $0.75 \mathrm{mg} / \mathrm{l}$ Mancozeb concentration and highly significant $(\mathrm{p}=0.019<0.01$ ) for the highest concentration ( $1 \mathrm{mg} / \mathrm{l}$ ) of which it increases by $63 \%$ compared to controls.

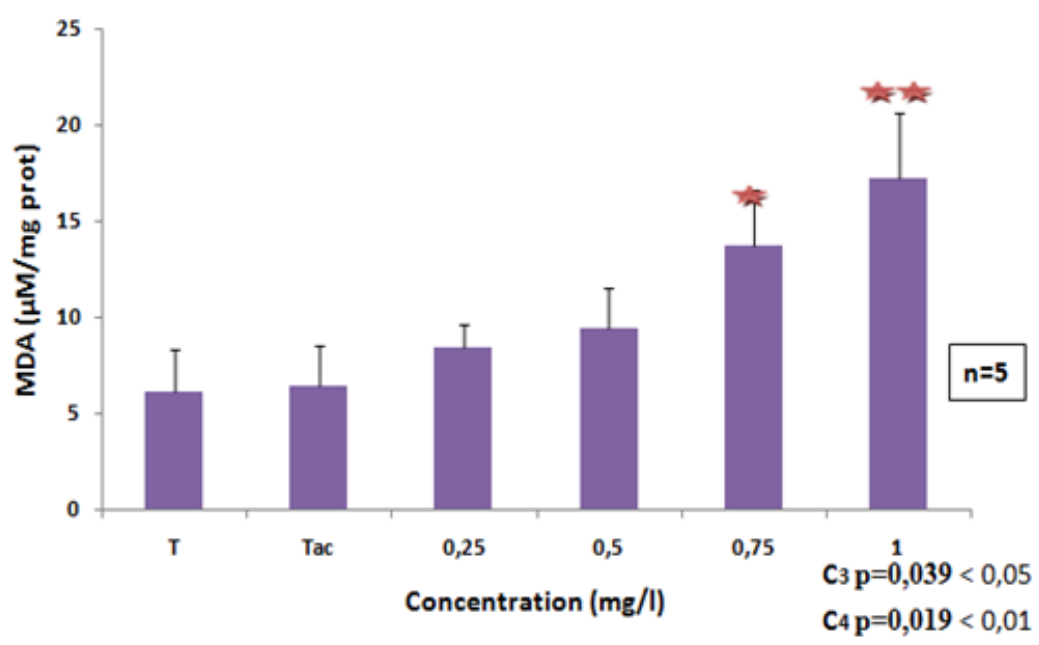

Figure 3 Effects of increasing Mancozeb concentrations on the variation of the mean MDA level in tadpoles (Rana Saharica).

\subsection{Evolution of Acetylcholinesterase activity}

Figure (4) illustrates the effect of Mancozeb on cholinesterase activity in tadpoles (Rana saharica). We see a significant decrease $(\mathrm{p}=0.05)$ in AChE enzyme activity after a 4-week exposure period (before metamorphosis) from 1.55 $\mathrm{nM} / \mathrm{min} / \mathrm{mg}$ protein. 105 in controls to $0.44 \mathrm{nM} / \mathrm{min} / \mathrm{mg}$ protein .105 in the highest concentration (1 mg/l) treated. Thus, this activity decreases by $72 \%$ in the highest concentration of Mancozeb treated patients compared to controls. 


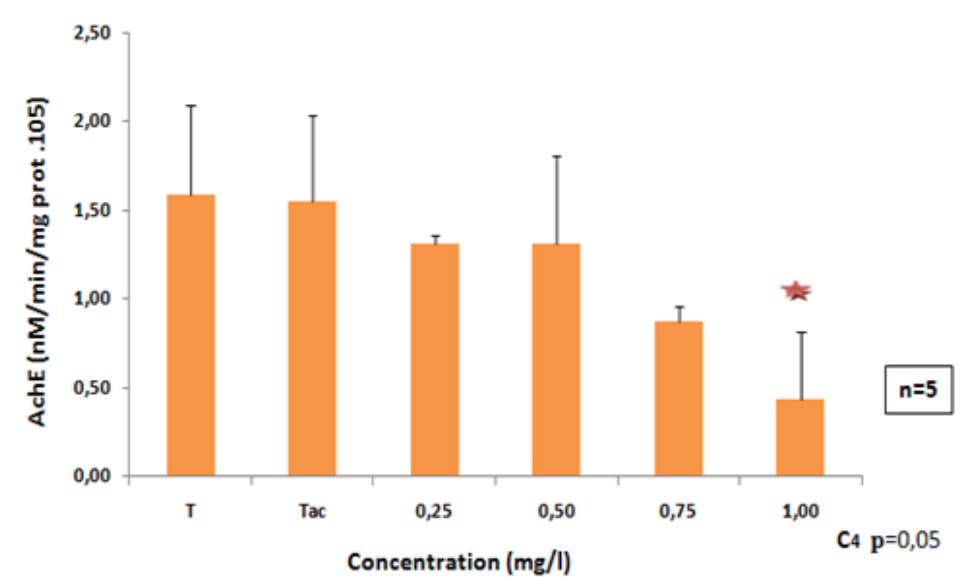

Figure 4 Effects of increasing Mancozeb concentrations on the evolution of AchE activity in tadpoles (Rana Saharica).

\subsection{Histological study}

Figure (5) shows the aspect of the liver tissue of the tadpoles. Histological examination has shown that the liver of tadpoles is not divided into distinct lobules as in most mammals. However, the periphery of the lobules is delimited by the portal spaces and their centre is occupied by a centrolobular vein (the VP portal vein) towards which the sinusoids (S) converge. The portal spaces, together with the portal vein (VP), include lymphatic channels $(\rightarrow)$ as well as the constituents of the portal triad, that is, the portal vein, a hepatic artery (A) and bile ducts (CB). We also notice rows of hepatocytes with bile ducts $(\rightarrow$ ) running between these hepatocytes separated by sinusoids (S) (Figure $5 \mathrm{a}$ and $\mathrm{b}$ ).

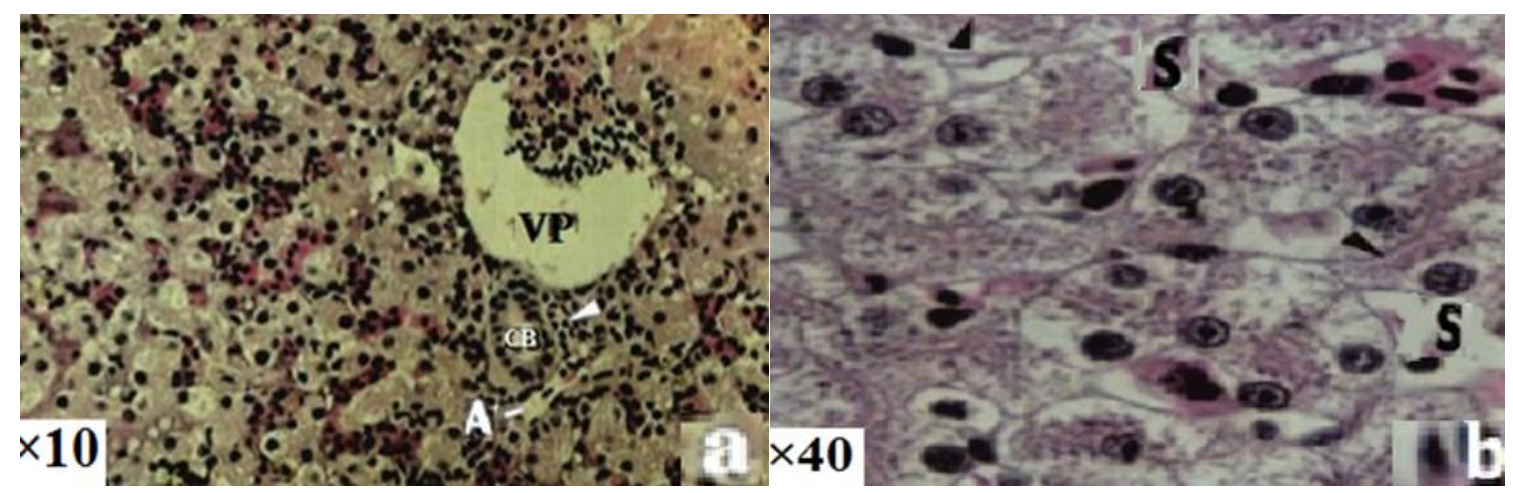

Figure 5 Histological section of the liver of a control tadpole (Rana saharica).

In the treated animals, we note that the hepatocytes of the tadpoles exposed to Mancozeb $(1 \mathrm{mg} / \mathrm{l})$ are deformed with a disturbance of the tissue architecture (Figure 6 a). The cytoplasm of the hepatocytes is more aerated than normal; the cellular organelles $(\rightarrow)$ are clustered near the bile ducticles. Areas of parenchyma in which the high number of necrotic cells gives a moth-like appearance are observed in these individuals (Figure $6 \mathrm{~b}$ ).

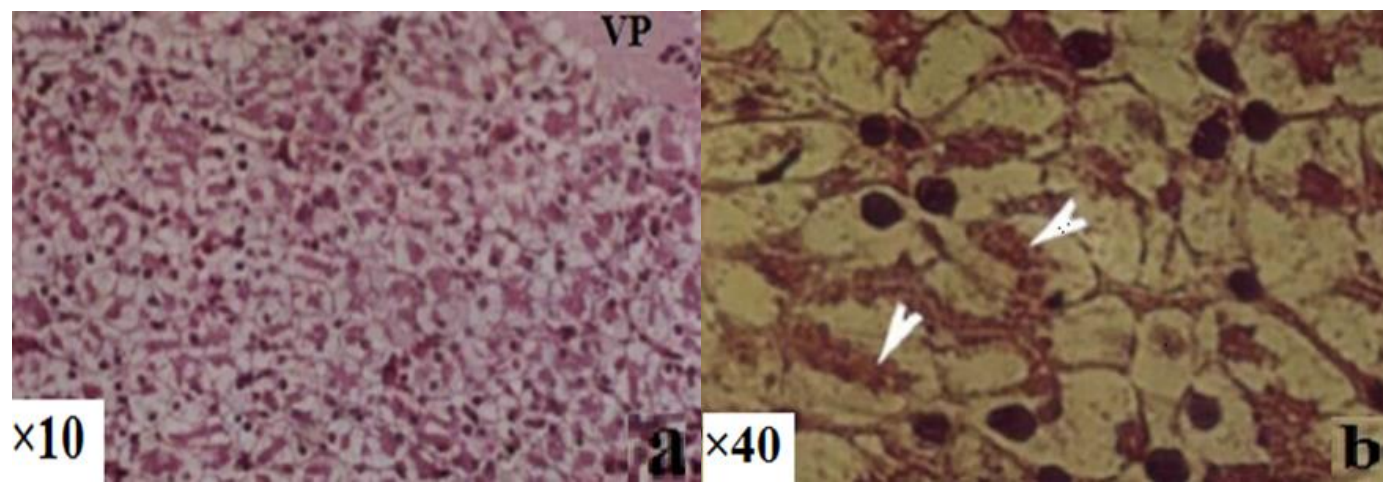

Figure 6 Histological section of the liver of a tadpole (Rana saharica) exposed to $1 \mathrm{mg} / \mathrm{l}$ of Mancozeb. 


\section{Discussion}

The green frog is one of the bio-indicator species of pollution that are very sensitive to the slightest variations in the ecosystem, and any change in their environment could have consequences on their embryonic development and physiology [16].

A wide range of contaminants and pollutants affect amphibian populations in terms of their lifespan and diversity: pesticides, fungicides, herbicides and fertilizers and many other molecules [17]. All of these xenobiotics are toxic directly by affecting the immediate environment of the animals or indirectly by reducing their growth through damage to their endocrine system or by inducing immunesuppression [17]. Furthermore, the nature and intensity of the toxic effects of a fungicide on an organism depend on its concentration in the target organs. This concentration is related to the administered dose, its distribution and metabolism [18].

Indeed, work by Benosmane et al. [7] carried out before this one concerning the survival of amphibians under the fungal xenoestrogen stress (Mancozeb), shows that in the presence of the latter, the growth of the tadpoles is inhibited; the toxicity of this xenobiotic in tadpoles manifests itself primarily through a delay in weight and height growth at all the concentrations tested $(0.25,0.50,0.75$ and $1 \mathrm{mg} / \mathrm{l})$. However, at the highest concentration, we recorded a mortality rate of more than $80 \%$ after 5 weeks of treatment.

This left us oriented towards the biochemical and metabolic aspect and to know the details of oxidative stress.

According to Lagadic et al. [19] and Nzengue [20], when the change (stress) is not intense and xenobiotic concentrations in the organism are still low, tadpoles deploy a battery of responses through the activation of their detoxification mechanisms in order to fight, survive and acclimatize to this new parameter. This is the case for the induction of metabolism/detoxification enzymes for xenobiotic management as long as the xenobiotic/enzyme balance is tilted towards the second parameter.

Oxidative stress is the consequence of an imbalance between oxidants and antioxidants in which the activity of the oxidant is greater than the capacity to neutralize the antioxidants [21]. Thus, there must be a balance between the formation and elimination of reactive oxygen species, in the normal case and the case of oxidative stress.

Among the enzymes involved in the protection of the organism against oxidative stress, we mainly distinguish: Superoxide Dismutase (SOD), Glutathione Peroxidase (GPX), glutathione S-transferase (GST) or Catalase (CAT). These enzymes are also inducible under chemical stress $[22,23]$. As a result, these enzyme systems are considered excellent biomarkers.

Indeed, our results showed a progressive increase in GST activity in tadpoles treated with the fungal xenoestrogen (Mancozeb) compared to controls. At the same time, results from the same study; monitoring the evolution of glutathione levels, which represents one of the first barriers against xenobiotic toxicity, revealed a decrease due to the establishment of detoxification mechanisms [1]; this decrease is due, on the one hand, to its spontaneous conjugation to the ultimate toxicants and, on the other hand, to its binding to GST.

Glutathione S-transferase (GST) is a family of specific enzymes that catalyze the conjugation of GSH with xenobiotics in phase II of metabolization, thereby favouring their elimination from the body [24, 25]. It plays a key role in the mechanism of detoxification of reactive oxygen ("ROS") species and the regulation of redox balance [26].

Catalase is also a defence system involved in detoxification mechanisms. We have shown an increase in Catalase activity in tadpoles treated with Mancozeb, probably for the degradation of oxygen radicals and the conversion of hydrogen peroxide (toxic to cells) into oxygen gas and water.

When antioxidant defense systems are saturated, ROS become abundant and their toxicity is manifested in particular by the phenomenon of lipid peroxidation itself, which causes an increase in the level of MDA, the final product of peroxidation. Malondialdehydes are considered as end products of the oxidation of polyunsaturated fatty acids and are specific biomarkers [27].

Many studies have shown the exacerbation of lipid peroxidation in aquatic organisms exposed to high concentrations of toxic substances, including endocrine disruptors [28]. Our results showed an increase in MDA levels in Rana saharica tadpoles. This increase in MDA level confirms the saturation of antioxidant systems and supports the increase in the ROS level in the blood of tadpoles treated with the same concentrations of our study [1]. 
Radical membranes attack causes membrane permeability perturbations related to the formation of lipid peroxides [29]; all components can be affected: lipids, proteins and therefore the membrane as a whole [30]. The same applies to DNA, the attack of which results in an increase in chronic pathologies [31]. Amamra et al. [32] stipulate that the specific effects of a radical attack are manifested at the cellular level by lipid peroxidation inducing pronounced disturbances in cellular functioning.

Apart from ROS, inhibition of acetylcholinesterase AchE is considered to be one of the major biomarkers of pesticide toxicity. Indeed, many toxicants, particularly insecticides, cause the chemical mediator to accumulate in synaptic spaces, resulting in tetany $[33,34]$. Inhibition of this enzyme is the direct reaction of the body to most neurotoxic insecticides.

In this work, we focused on the neurotoxicity of Mancozeb primarily due to its high lipophilicity, and measurement of AChE activity revealed a neurotoxic effect of Mancozeb.

The other aspect that we have addressed in this work, concerns the possible disturbances to tissue that may be generated by the presence of Mancozeb in the tadpole milieu. We focused on the liver because of its strong involvement in the metabolism phenomenon and because this organ is the obligatory passage for most xenobiotics.

The normal cell undergoes mechanical, chemical and other lesions during a chemical aggression, this provokes changes such modifications which result in a rupture of the plasma membrane and a release of the intracellular contents which causes an inflammatory reaction which is a major response of the body's defense against external aggressions which explains the induced cellular necrosis.

\section{Conclusion}

All observations converge on an induction of oxidative stress; the higher the concentration of Moncozeb, the greater the production of reactive oxygenated metabolite derivatives. Therefore, an enzymatic and non-enzymatic antioxidant system intervenes for the detoxification of the cell and protection against superoxide ions and hydrogen peroxides prevent the formation of the hydroxyl radical $\mathrm{OH}^{\circ}$ (the most reactive species which is not detoxifiable by enzymes). As a result, the oxidative stress induced induces lipid peroxidation at the level of cell membranes or membranes of other organelles as well as neurotoxicity. All these alterations cause cellular dysfunction. If these alterations are not repaired, this leads to inflammation, malformations or cell cycle arrest, or in high doses it causes death of the organism.

\section{Compliance with ethical standards}

\section{Acknowledgments}

The authors express their sincere thanks to the Laboratory of Cellular Toxicology of the Badji Mokhtar University in Annaba, Algeria, for carrying out this research work.

\section{Disclosure of conflict of interest}

The author declares no conflict of interest.

\section{References}

[1] Benosmane S. Impact d'un mimétique œstrogène (MOS) sur un organisme bio indicateur de pollution: R. saharica. Ph.D. thesis, Badji Mokhtar University of Annaba, Algeria. 2015; 57-71.

[2] Taylor JR, Selhorst JB, Houff SA, Martinez AJ. Chlordecone intoxication in man. I. Clinical observations Neurology. 1978; 28: 626-30.

[3] Echaubard M. L'environnement en France. Rapport sur l'état de l'environnement en France, Edition 1994-1995. Le courrier de la Nature. 1995; 152: 31-35.

[4] Boulenger GA. On a collection of batrachians and reptiles made by Dr. H.G.F. Spurrell, F.Z.S., in: the Choco, Colombia. In Proceeding of the Zoological Society of London. 1913; 83(4), 1019-1038.

[5] Geniez P, Mateo JA, Geniez M, Pether J. The amphibians and reptiles of the Western Sahara. Edition Chimaira, Frankfurt am Main, Germany, Chimaira. 2004; 229. 
[6] Lyman WR, Lacoste RJ. New developments in the chemistry and fate of ethylene-bisdithiocarbamate fungicides. In Environmental Quality and Safety: Supplement. 1975; 3: 67- 74.

[7] Benosmane S, Djebar MR, Berrebah H, Alayat A, Benamara M, Zouaghi MF, Amamra R. Toxicological impact of a mimetic estrogen specie: mancozeb on a tadpoles of the green frog (Rana saharica). Journal of Biodiversity and Environmental Sciences (JBES). 2015; 6(3): 307-314.

[8] Gosner KL. A Simplified table for staging anuran embryos and larvae with notes on identification. Herpetologica. 1960; 16: 183-190.

[9] Bradford MM. A rapid and senstive method for the quantitation of microgram quantities of protein utilizing the principe of protein-dye binnding. Anal. Biochem. 1976; 72: 248-254.

[10] Habig WH, Pabst MJ, Jakoby WB.Glutathione S-transferases. The first enzymatic step in mercapturic acid formation. J Biol Chem. 1974;249 (22): 7130-7139.

[11] Regoli F, Principato G. Glutathione, glutathione-dependant and antioxidant enzymes in mussel Mytilus galloprovincialis exposed to metals under field and laboratory conditions: implication for the biomarkers. Aquatic Toxicology. 1995; 31: 143-164.

[12] Draper HH, Hadley M. Malondialdehyde determinationas index of lipid peroxidation. Methods in Enzymology. 1990; 186: 421-431.

[13] Ellman GL, Courtney KD, Andres V, Featherstone RM. A new and rapid colorimetric determination of acetylcholinesterase activity. Biochemical Parmacology and Physiology. 1961; 38: 84-90.

[14] Dagnelie P. Statistiques théoriques et appliquées. Tome 2: références statistiques à une et à deux dimensions, 3e edition. Univ Boeck et Larcier, Bruxelles. 1999; 659.

[15] Martoja R, Martoja M. Initiation aux techniques de l'histologie animale. Masson et Cie, Paris. $1967 ; 1: 323$.

[16] Joly P. Invasions biologiques: état de l'art et perspectives. Revue d'Ecologie (La Terre et la Vie). 2000; 7, 21-35.

[17] Sparling DW, Linder G, Bishop CA. Ecotoxicology of amphibians and reptiles. In: SETAC Press, Pensacola, FL. 2000; 325.

[18] Mückter H. What is toxicology and how does toxicity occur?. Best Practice and Research Clinical Anaesthesiology. 2003; 17: 5-27.

[19] Lagadic L, Caquet T, Ramade F. The role of biomarkers in environmental assessment (5). Invertebrate populations and communities. Ecotoxicology. 1994;3: 193- 208.

[20] Nzengue Y. Comparaison des mécanismes de toxicité redox du cadmium, du cuivre et du zinc: place des Métallothionéines et de p53. Ph.D.thesis, Joseph fourier University, Grenoble. 2008; 297.

[21] Lykkesfeldt J, Svendsen 0. Oxidants and antioxidants in disease: oxidative stress in farm animals. The Veterinary Journal. 2007; 173: 502-511.

[22] Kappus H. Oxidative stress in chemical toxicity. Archives of toxicology. 1987; 60 (1-3): 144-149.

[23] Winston GW, Di Giulio RT. Prooxidant and anti- oxidant mechanisms in aquatic organisms. Aquat. Toxicol. 1991; 19: $137-161$.

[24] Leaver MJ, clarke DJ, George SD. Molecular studies of the phase 11 xenobiotic conjugative enzymes of marine pleuronectid flatfish. Aquat. Toxicol. 1992; 22: 265-278.

[25] Malmezat T, Breuille D, Capitan P, Mirand PP, Obled C. Glutathione turnover is increased during the cute phase of sepsis in rats. J. Nutr. 2000; 130: 1239-1246.

[26] Siritantikorn A, Johansson K, Ahlen K, Rinaldi R, Suthiphongchai T, Wilairat P, Morgenstern R. Protection of cells from oxidative stress by microsomal glutathione transferase 1. Biochem. Biophys. Res. Commun. 2007; 355: 592596.

[27] Box A, Sureda A, Galgani F, Pons A, Deudero S. Assessment of environmentalpollution at Balearic Islands applying oxidative stress biomarkers in the mussel Mytilus galloprovincialis. Comp. Biochem. Physiol. C Toxicol. Pharmacol. 2007; 146: 531-539.

[28] Ibn Hadj Hassine A. Evaluation de l'activité oestrogénique de contaminants et developpement d'un bio-recepteur d'affinité pour la detection d'une xéno-hormone. PhD Thesis, Ecole National Supérieure des Mines, Saint-Etienne. $2017 ; 174$. 
[29] Bouaricha H, Berrebbah H, Grara N, Djebar MR.Response of Paramecium sp. with respect to an insecticide (Proclaim): growth, content of MDA, AChE activity and respiratory metabolism. Journal of Applied Sciences Research. 2012; 8(8): 4172-4180.

[30] Halliwell B, Chirico S. Lipid peroxidation: its mechanism, measurement, and significance. The American Journal of Clinical Nutrition. 1993; 57: 715-724.

[31] Curtin JF, Donovan M, Cotter TG. Regulation and measurement of oxidative stress in apoptosis. Journal of immunological methods. 2002; 265: 49-72.

[32] Amamra R, Djebar MR, Moumeni O, Azzouz Z, Zeriri I, Atailia A, Benosmane S, Berrebbah H. Lipid peroxidation, oxidative stress and respiratory metabolism alteration in the freshwater ciliate Paramecium tetraurelia exposed to cypermethrin, a pyrethroid insecticide. Journal of Biodiversity and Environmental Sciences (JBES). 2015; 6(4): 115-123.

[33] Burgeot T, Boquene G, Porte C, Dimmet J, Santella RM, PfholLeszkowies A, Raoux G, Galgani. Bioindicators of polluant exposure in the Northwestern mediteranean sea. Mar.Ecol.Prog. Ser. 1996; 131: 125-141.

[34] Bainy ACD. Biochimical responses in peneids caused by contaminants. Aquaculture. 2000; 191: 163-168. 